\section{Hepatitis C virus and HIV type 1 co-infection}

\section{Priyanka Gupta}

Retroviral Genetics Division, Centre for Virus Research, Westmead Millennium Institute, Sydney, Australia

\section{Abstract}

Around 33 million people worldwide are living with Human Immunodeficiency Virus (HIV) infection, and approximately $20-30 \%$ of HIV-infected individuals are also infected with Hepatitis $\mathrm{C}$ virus (HCV). The main form of HCV transmission is via the blood borne route; high rates of co-infection are found in intravenous drug users with $\mathrm{HCV}$ prevalence rates as high as $90 \%$. Introduction of effective antiretroviral therapy (ART) has led to a significant decline in HIV-related morbidity, but at the same time the incidence of HCV related liver disease is increasing in the co-infected population. Meta analysis has revealed that individuals who are co-infected with HIV/HCV harbor three times greater risk of progression to liver disease than those infected with HCV alone. Increased risk of progression to Acquired Immunodeficiency Syndrome (AIDS) and AIDS-related deaths is shown among the co-infected patients by some studies, suggesting that HCV infection may accelerate the clinical course of HIV infection. HCV may also affect the incidence of liver toxicity associated with ART, affecting the management of HIV infection. There is a lack of optimal therapeutic approaches to treat HCV infection in HIV co-infected patients. This review discusses recent literature pertaining HIV/HCV co-infection, in addition to providing a snapshot of impact of co-infection on human genome at the level of gene expression and its regulation by microRNAs (miRNAs).

\section{Epidemiology of Hepatitis C virus/HIV co-infection}

Globally, an estimated 170 million people are infected with Hepatitis C virus (HCV) and 33 million people are infected with HIV. About $20-30 \%$ of HIV infected patients in USA are infected with $\mathrm{HCV}$, owing to the shared modes of transmission. ${ }^{1} \mathrm{HCV}$ is spread 10 times more efficiently than HIV through percutaneous blood exposures; although co-transmission of both viruses can happen, co-infected individuals are usually infected first with $\mathrm{HCV}^{2,3}$ Primary mode of acquisition of $\mathrm{HCV}$ is through injection drug abuse in various settings. Transfusion of contaminated blood and blood products was once an important mode of transmission of HCV and HIV but is now rare because of effective screening procedures. ${ }^{4,5}$

HCV is spread less efficiently by sexual transmission than HIV. ${ }^{6-9}$ In hemophiliacs coinfected with HIV and HCV, HIV infection was detected in $13 \%$ and HCV in only $3 \%$ of 162 female sexual partners of hemophiliacs. ${ }^{8}$ However, multiple outbreaks of HCV infection have been seen in HIV-infected men who have sex with men (MSM), and have no percutaneous risk factors. These are attributed to the high-risk sexual practices such as unprotected receptive anal intercourse and recreational drug use has also been reported in these men. ${ }^{10-12}$ Vertical transmission from a HCV infected mother to her newborn child is uncommon; the reported risk of transmission ranges between $2-5 \%$, with the risk three fold higher if the mother is also HIV seropositive. ${ }^{13}$

\section{Clinical picture of Hepatitis C virus/HIV co-infection}

\section{Influence of Hepatitis $C$ virus} infection on natural course of HIV infection

The effect of HCV infection on HIV disease is not clear. Early studies suggested that there was no association between HIV-HCV co-infection and poor disease outcome. These studies suggested that although the co-infected patients had higher rate of liver-related mortality, there was no increased risk of AIDS and mortality rates as compared to HIV monoinfected individuals. ${ }^{14,15}$ Kaufmann et al. demonstrated that HCV seropositive patients had smaller increase in $\mathrm{CD}^{+} \mathrm{T}$ lymphocytes than HCV seronegative patients. But this disappeared during the duration of 4 years of the follow up. ${ }^{14}$ Rockstroh et al. did not find any effect on HCV serological status on HIV disease progression, but there was an increased risk of liver-related deaths among the coinfected patients. ${ }^{15}$

However, more recent studies have suggested that co-infection is associated with greater risk of progression to AIDS or death, despite similar use of antiretroviral therapy (ART) within the mono-infected and co-infected groups. Greub et al., ${ }^{16}$ in the Swiss Cohort study, demonstrated that $\mathrm{HCV}$ infection, in combination with intravenous drug abuse are significant risk factors in the morbidity and mortality between HIV infected subjects. The authors concluded that following antiretroviral therapy and during a mean follow up of 42
Correspondence: Priyanka Gupta, Retrovira Genetics Division, Centre for Virus Research, Westmead Millennium Institute, Darcy Road, Westmead NSW 2145, Sydney, Australia.

Tel. +61.298459120 - Fax: +61.298459103

E-mail: pgup7905@uni.sydney.edu.au

Key words: HIV, Hepatitis C Virus, co-infection, miRNA, antiretroviral therapy.

Acknowledgements: this review is a part of $\mathrm{PhD}$ dissertation of Priyanka Gupta who is a recipient of Australian Postgraduate Award by the University of Sydney. PG thanks Dr. Nitin Saksena for his assistance during the preparation of this review.

Conflict of interests: the author declares no potential conflict of interests.

Received for publication: 19 February 2013. Accepted for publication: 19 February 2013

This work is licensed under a Creative Commons Attribution NonCommercial 3.0 License (CC BYNC 3.0).

(C) Copyright P. Gupta, 2013

Licensee PAGEPress, Italy

Infectious Disease Reports 2013; 5:s1e7

doi:10.4081/idr.2013.s1.e7

months; there was a negative effect on the magnitude of $\mathrm{CD}^{+}{ }^{+} \mathrm{T}$ cell reconstitution among patients with co-infection. ${ }^{16}$ Similarly in an Italian cohort study, De Luca et al. showed a shorter time to the clinical progression of HIV disease in co-infected patients after starting ART during a follow up of 36 months. ${ }^{17} \mathrm{~A}$ review in the favor of co-infection impairing HIV-specific responses comes from a meta-analysis of 8 different trials involving 6216 patients, which clearly showed that the magnitude of immune system recovery in HIVHCV co-infected individuals was slower than the HIV-mono-infected individuals alone. ${ }^{18}$

High levels of $\mathrm{T}$ cell activation were also seen in co-infected individuals as compared to HCV non-infected individuals even following ART. ${ }^{19-21}$ This activation of $\mathrm{T}$ cells can cause immune dysfunction and cytokine production leading to increased replication rates of HCV and HIV and lower CD4 ${ }^{+} \mathrm{T}$ cell counts. ${ }^{20}$ High levels of activated $\mathrm{CD} 8+\mathrm{T}$ cells were associated with HCV viremic but not HCV seronegative women, and were also associated with incident AIDS among these groups. ${ }^{19,20}$

However, the impact of HCV infection on $\mathrm{CD}^{+}{ }^{+} \mathrm{T}$ cell recovery following ART is conflicting; some reports note a poorer $\mathrm{CD}^{+}{ }^{+} \mathrm{T}$ cell response in co-infected compared to monoinfected patients, ${ }^{22}$ and others do not. ${ }^{23-27} \mathrm{Co}$ infection with $\mathrm{HCV}$ may cause $\mathrm{CD} 4^{+} \mathrm{T}$ cell 
apoptosis in HIV-untreated patients and more rapid progression to severe immunodeficiency however this effect is rapidly lost with effective ART. ${ }^{23}$ Sulkowski et al. showed that there was no difference in the increase of $\mathrm{CD} 4^{+} \mathrm{T}$ count during ART in HCV infected individuals as compared to HCV un-infected individuals. ${ }^{27}$

\section{Influence of HIV infection on natural course of Hepatitis $C$ virus infection}

While there has been a significant decline in HIV related morbidity due to more effective therapy, incidence of $\mathrm{HCV}$ related liver disease is still increasing in the co-infected population. As early as 1993, it was reported that HCV RNA levels were higher in people with hemophilia who were co-infected with HIV and HCV, than in those who remained HIV negative, and liver failure was shown exclusively in coinfected patients. ${ }^{28}$ While approximately $20 \%$ of HCV mono-infected patients clear the virus but HCV clearance occurs in only $5-10 \%$ of coinfected individuals, ${ }^{29}$ especially in patients with lower CD4+ T cell counts. ${ }^{30}$ Infection with HIV has been associated with higher HCV RNA viral load and more rapid progression of cirrhosis, liver failure, and hepatocellular carcinoma. ${ }^{31-34}$ In a meta analysis of 8 studies, the average risk of progression to cirrhosis or decompensated liver disease is 3 times higher in HCV-HIV co-infection than HCV mono-infection. ${ }^{35}$ Similarly, a recent meta analysis of 17 studies showed that $21 \%$ of co-infected individuals progress to cirrhosis after 20 years of infection and $49 \%$ after 30 years. ${ }^{36}$

Studies analyzing the effect of ART on the natural history of Hepatitis $\mathrm{C}$ have been contradictory. Some studies suggest that there is a lower risk of liver mortality in patients who have received effective $\mathrm{ART}, 37,38$ while other studies suggest that among persons with effectively controlled HIV infection, the progression of fibrosis was similar in persons with or without HIV infection. ${ }^{39,40}$ In a meta-analysis involving 27 studies, Thein et al. did not detect any significant association between ART and the risk of cirrhosis. ${ }^{36}$ Increased risk of cirrhosis in patients with co-infection relative to those with mono-infection was similar in person taking ART and those not taking ART.

However, despite the positive impact of ART, as shown by some studies, some studies do not show any benefit of ART. ${ }^{41,42}$ Increased risk of hepatitis/liver-related deaths were seen in a 20 year prospective study despite the use of ART among co-infected drug users (DUs) compared to HCV mono-infected DUs, providing further evidence that HIV accelerates liver disease. ${ }^{43}$

Furthermore, some studies have shown an association of ART with increased hepatic injury as suggested by elevated liver transaminases or frank liver decompensation. ${ }^{44-48}$

\section{Medical management of co-infected patients}

\section{Before initiation of antiretroviral therapy}

HIV infected patients who are also HCV seropositive should be tested for the presence of HCV RNA using a qualitative or quantitative assay to confirm the presence of active infection. ${ }^{49} \mathrm{Co}$ infected patients should be advised to abstain from alcohol, hepatotoxic drugs and vaccinated against Hepatitis A and Hepatitis B viruses. The treatment for $\mathrm{HCV}$ follows standard guidelines. ${ }^{50}$ The $\mathrm{CD} 4^{+} \mathrm{T}$ cell count is an important determinant for the treatment response in the co-infected patients; the higher it is the greater the chances of response to anti-HCV therapy. ${ }^{51}$ Patients with CD4+ T cell counts $>500$ cells $/ \mathrm{mm}^{3}$ are good candidates for treatment of $\mathrm{HCV}$, while in patients with lower $\mathrm{CD} 4^{+} \mathrm{T}$ cell counts (e.g. $<200$ cells $/ \mathrm{mm}^{3}$ ), it may be preferable to initiate ART and delay HCV therapy until $\mathrm{CD}^{+}{ }^{+} \mathrm{T}$ cell counts increase as a result of HIV treatment. ${ }^{49,52-54}$

\section{Antiretroviral therapy in $\mathrm{HIV} /$ Hepatitis C virus co-infection}

Patients with lower $\mathrm{CD} 4^{+} \mathrm{T}$ cell counts (e.g. $<200$ cells $/ \mathrm{mm}^{3}$ ) should be given ART as a priority and these patients can be considered as candidates for anti-HCV therapy once the $\mathrm{CD} 4^{+} \mathrm{T}$ cell counts rise above 200 cells/ $/ \mathrm{mm}^{3} .55-57$ If both HIV and HCV treatments are indicated, the choice of ART regimen should be guided by the HCV treatment regimen selected with careful consideration of potential drug-drug interactions and overlapping toxicities. Additionally, certain ART drugs should be avoided because they have been associated with higher incidence of serious liver-associated adverse effects, such as fatty liver disease with nucleoside reverse transcriptase inhibitors (NRTIs) such as Zidovudine or Didanosine. ${ }^{58}$ Clinical and laboratory monitoring for adverse effects should be done with the help of laboratory tests such as hemoglobin, amylase, lipase and serum transaminase levels. The use of ARTs may be maintained as long as the serum transaminase levels do not go above 3.5 fold of the normal values. If serum transaminase concentrations increase above this threshold, then different decisions may be taken e.g. start anti-HCV therapy (if indicated), switch to an alternative regimen, or discontinue the therapy immediately if a hypersensitivity reaction occurs.

\section{Gene expression profiling in HIV/Hepatitis C virus co-infection}

Genomic analysis of liver biopsies and
PBMC (Peripheral Blood Mononuclear Cells) with the help of techniques like microarray analysis and PCR (Polymerase chain reaction) provide a unique opportunity to study the HCVhost interaction in the presence and absence of HIV co-infection. The use of the gene expression profiling may allow the identification of novel biomarkers by comparing the differences in gene expression in PBMCs and liver biopsies of individuals with different stages of fibrosis.

Co-infected patients had decreased intrahepatic inflammatory cytokine mRNA levels, with a notable decrease in IFN- $\gamma$ compared with mono-infected patients consistent with other studies. ${ }^{59-63}$

Gonzalez et al. assessed cytokine levels in liver biopsies on liver samples from HCV/HIV co-infected and HCV mono-infected patients. They measured IFN- $\gamma$, Tumor Necrosis Factor (TNF)- $\alpha$, Transforming Growth Factor (TGF)$\beta 1$, interleukin (IL)-4, IL-10, IL-12p35 and IL12p40 mRNA levels by real-time PCR performed on liver biopsies of HCV mono-infected $(n=19)$ and HCV/HIV co-infected $(n=24)$ patients (Table 1). ${ }^{59-67}$ The results showed that the co-infected patients had decreased intrahepatic mRNA levels of IFN- $\gamma$, IL-4 and IL-12p35 compared with mono-infected patients while IL-10 was increased. Intrahepatic IFN- $\gamma$ levels were also significantly reduced in patients with advanced immunodeficiency. $^{64}$ IFN- $\gamma$ mRNA levels increased linearly with increasing peripheral CD4+ $\mathrm{T}$ cell counts by 1.23 times for every 100 $\mathrm{CD} 4{ }^{+} \mathrm{T}$ cells $/ \mathrm{mm}^{3}$ increase.$^{64}$ Decreased numbers of intrahepatic $\mathrm{CD} 4^{+} \mathrm{T}$ cells in HCV/HIV co-infected patients, shown in this study, may suggest that patients with very low $\mathrm{CD} 4^{+} \mathrm{T}$ cell numbers may have decreased IFN- $\gamma$ secretion that may be permissive for accelerated fibrogenesis (Table 1).$^{3,59-70}$ Flynn et al. looked at the effect of HIV infection on natural interferon production with HCV by directly comparing HCV specific T-cell responses and cytokine profiles of 40 Australian Trial in Acute Hepatitis C (ATAHC) participants with acute hepatitis $\mathrm{C}, 20$ of them were HIV/HCV co-infected and 20 of them HIV seronegative. ${ }^{63}$ The study showed that HIV incurs detrimental effect on HCV-specific cytokine production in people with acute hepatitis $\mathrm{C}$, with notable decrease in Interferon (IFN- $\gamma$ ). The response to this interferon was significantly lower in magnitude and smaller in breadth uniquely in the HIV/HCV group. The reduced interferon production was associated with lower peripheral CD4+ ${ }^{+}$-cell counts, but not with detectable HIV viral load. ${ }^{63}$

Abbate et al., analyzed mRNA levels for IFN- $\alpha$, IFN- $\gamma$, IFNAR-1 and protein kinase R (PKR) in liver biopsies of HCV/HIV-co-infected patients to compare their levels with those found in singly HCV-infected individuals. In HCV/HIV-co-infect- 
ed patients intra-hepatic IFN- $\alpha$ mRNA levels were up-regulated compared with HCV-monoinfected patients, whereas IFN- $\gamma$, interferon- $\alpha / \beta$ receptor-1 (IFNAR-1) and PKR were profoundly down-regulated. ${ }^{59}$ IFN- $\gamma$ up-regulates IFNAR-1 and it is likely that the absence of mRNA for both factors in the liver of co-infected patients may be causally related. ${ }^{71}$ IFN- $\alpha$ is shown to be up-regulated, presumably driven by HIV, but the absence of the IFNAR1 suggests that there is an impaired ability to respond to IFN- $\alpha$. PKR is also virtually absent supporting the above fact (Table 1). ${ }^{59}$ Blackard et al., retrospectively examined cytokine expression in HCV mono-infected and HCV/HIV co-infected individuals to determine how HIV specifically alters the intrahepatic environment observed during chronic HCV infection. They used real-time PCR to quantify cytokines that contribute to innate and adaptive immune responses, summarized in Table 1 . The results showed that the detection rates of cytokine mRNAs were lower for HCV/HIV co-infected group compared to the HCV mono-infected group; the detection rates for TNF $\alpha$, IL-8, and IL10 were statistically significant. Overall, cytokine mRNA quantities were lower for
HCV/HIV co-infected compared to HCV monoinfected persons, with the exception of TGF $\beta 1$ (Table 1). TGF $\beta 1$ is a potent inducer of fibrogenesis in the effector cells of hepatic fibrosis and HIV co-infection may further contribute to liver fibrosis in HCV-positive persons by inducing TGF $\beta 1$ expression. TGF $\beta 1$ production has been shown to reduce the IFN $\gamma$ response of $\mathrm{CD}^{+} \mathrm{T}$ cells to viral infection. ${ }^{72}$ This may suggest an important mechanism by which HIV, through increased TGF $\beta 1$ and decreased IFN $\gamma$ expression, may promote HCV persistence. This data suggests that defects in cytokine activation may occur in HCV/HIV co-infected persons that limit efficient clearance of HCV from the liver. ${ }^{60}$ Kottilil et al. demonstrated higher expression of Interferon inducible genes (IFIG) in $\mathrm{HCV}$ patients co-infected with HIV suggesting that HIV infection is a major driving factor in turning on the type-I IFN signature expression. Moreover, the IFIG expression, which is highly predictive of the therapeutic response to IFN- $\gamma$ based therapy, is expressed at a higher level in HIV-infected individuals. This reiterates a mechanistic role for type-I IFN $\gamma$ baseline hyperexpression in vivo in HCV/HIV-co-infected individ- uals who fail to clear HCV with IFN $\gamma$ therapy. HCV-mono-infected and HIV/HCV individuals had increased serum levels of markers of liver fibrosis compared to seronegative HIV individuals and HIV-infected individuals without liver disease. Some immune markers such as Natural killer cell p30-related protein (NKp30) and Insulin-like Growth Factor 1 (IGF-1) Receptor (IGF-R1) up-regulated among patients with HCV with or without HIV co-infection, whereas some others selectively up-regulated in HCV mono-infected subjects (Table 1). ${ }^{65}$ In contrast to above mentioned studies, Walters et al. showed that global gene expression does not differ between HCV mono-infected and HCV/HIV co-infected individuals. ${ }^{61}$ However, a subset of patients showed a specific pattern of gene expression known as enhanced gene expression patterns $\left(\mathrm{EGE}^{+}\right)$. This group contained two $\mathrm{HCV}$ and four HCV/HIV-infected individuals. Specifically, the EGE (+) patients show decreased expression of multiple genes associated with the FAS apoptosis pathway and increased expression of lymphocyte adhesion molecules and lymphocyte-specific genes. Patients with EGE (+) also had partially

Table 1. Gene expression studies showing identified genes known to be altered during Hepatitis C Virus/HIV co-infection.

\begin{tabular}{|c|c|c|c|}
\hline Study & Sample/technique & Number of patients & Important findings \\
\hline Abbate et al. $2004^{59}$ & mRNA extraction and RT-PCR on liver biopsies & $\begin{array}{l}\text { HCV infected patients and } 20 \\
\text { V/HCV co-infected patients }\end{array}$ & $\begin{array}{l}\downarrow \text { Intrahepatic mRNA levels of IFN- } \gamma \text {, IFNAR-1, PKR } \\
\& \uparrow \text { IFN- } \alpha \text { levels in co-infected patients as } \\
\text { compared to mono-infected patients }\end{array}$ \\
\hline Blackard et al. $2006^{60}$ & mRNA extraction and RT-PCR on liver biopsies & $\begin{array}{l}12 \mathrm{HCV} \text { infected and } 14 \\
\text { HCV/HIV co-infected patients }\end{array}$ & $\begin{array}{l}\downarrow \text { Intrahepatic mRNA levels of TNF- } \alpha \text {, IL- } 8 \text {, and } \\
\text { IL-10 \& } \uparrow \text { TGF- } \beta 1 \text { levels in co-infected patients as } \\
\text { compared to mono-infected patients }\end{array}$ \\
\hline Walters et al. $2006^{61}$ & $\begin{array}{l}\text { mRNA extraction and microarray analysis on } \\
\text { liver biopsies }\end{array}$ & $\begin{array}{l}12 \text { HCV infected and } 16 \\
\text { HCV/HIV co-infected patients }\end{array}$ & $\begin{array}{l}\text { No difference in global gene expression between } \\
\text { mono-infected and co-infected individuals }\end{array}$ \\
\hline Zhao et al. $2012^{62}$ & $\begin{array}{l}\text { mRNA extraction and microarray analysis on } \\
\text { CD8+ T cells }\end{array}$ & $\begin{array}{l}24 \mathrm{HCV} \text { infected, } 24 \\
\text { HIV/HCV co-infected patients }\end{array}$ & $\begin{array}{l}16 \text { genes up-regulated in co-infection } 56 \text { genes } \\
\text { down-regulated in co-infection } \& \downarrow \text { IFN- } \gamma \text {, IL-2 }\end{array}$ \\
\hline Flynn et al. $2012^{63}$ & $\begin{array}{l}\text { HCV peptide enzyme-linked immunospot and } \\
\text { multiplex in vitro cytokine production assays }\end{array}$ & $\begin{array}{l}20 \mathrm{HCV} \text { infected and } 20 \\
\text { HIV/HCV co-infected patients }\end{array}$ & $\begin{array}{l}\downarrow \text { IFN- } \gamma \text { production showing good correlation with } \\
\text { CD4 } 4^{+} \text {T cell count }\end{array}$ \\
\hline Gonzalez et al. $2008^{64}$ & mRNA extraction and RT-PCR on liver biopsies & $\begin{array}{l}19 \text { chronic HCV infected and } 24 \\
\text { HCV/HIV co-infected patients }\end{array}$ & $\begin{array}{l}\downarrow \text { Intrahepatic mRNA levels of IFN- } \gamma \text {, IL-4, IL- } 12 \text { p35 } \\
\& \uparrow \text { IL-10 levels in co-infected patients as } \\
\text { compared to mono-infected patients }\end{array}$ \\
\hline Kottilil et al. $2009^{65}$ & $\begin{array}{l}\text { mRNA extraction and microarray analysis on } \\
\text { PBMC. Validation of selected genes by } \\
\text { microarray flow cytometry and ELISA }\end{array}$ & $\begin{array}{l}7 \mathrm{HCV} \text { infected, } 5 \\
\text { HCV/HIV co-infected patients }\end{array}$ & $\begin{array}{l}\text { NKp30 and IGF-R1 among patients with HCV with } \\
\text { or without HIV co-infection } \uparrow \text { CD10, CD80, CCL7, } \\
\text { CCL20, and CX3CL1 in HCV infection }\end{array}$ \\
\hline Rasmussen et al. $2012^{66}$ & $\begin{array}{l}\text { mRNA extraction and microarray analysis on } \\
\text { liver biopsies and PBMC }\end{array}$ & $\begin{array}{l}10 \mathrm{HCV} \text { infected and } 13 \\
\text { HCV/HIV co-infected }\end{array}$ & $\begin{array}{l}\text { Liver: } 250 \text { genes related to infectious disease and } \\
\text { immune responses were up-regulated } \\
\text { PBMC: } 271 \text { genes associated with inflammatory } \\
\text { responses, antigen presentation, and humoral } \\
\text { immune responses, as well as hematological, } \\
\text { immunological, and inflammatory diseases } \\
\text { up-regulated }\end{array}$ \\
\hline Kuntzen et al. $2008^{67}$ & mRNA extraction and RT-PCR on liver biopsies & $\begin{array}{l}33 \text { HCV infected and } 40 \\
\text { HIV/HCV co-infected patients }\end{array}$ & $\begin{array}{l}\text { IFN } \gamma \text {, RANTES, MIP-1 } \alpha \text { and IP-10 in } \\
\text { HIV/HCV-co-infected patients compared with } \\
\text { HCV-mono-infected patients }\end{array}$ \\
\hline
\end{tabular}

mRNA, messenger RNA; RT-PCR, real time-polymerase chain reaction; ELISA, enzyme linked immunosorbent assay; HCV, Hepatitis C virus; IFN, Interferon; IL, Interleukin; IFNAR, Interferon alpha receptor 1; PKR, protein kinase R; TNF, tumor necrosis factor; TGF, transforming growth factor; NKp30, natural killer cell p30-related protein; IGF-R1, insulin-like growth factor 1 receptor; CD, cluster of differentiation; CCL, chemokine (C-C motif) ligand; CX3CL1, Chemokine (C-X3-C motif) ligand 1; RANTES, regulated and normal T cell expressed and secreted, MIP-1 $\alpha$, macrophage inflammatory protein-l $\alpha$; IP10, interferon inducible protein 10. 
impaired Type I and II IFN-mediated antiviral responses with decreased antifibrogenic cytokine IFN- $\gamma$, supporting the above studies (Table 1).$^{61}$ Rasmussen et al. did gene expression analysis on paired liver biopsy samples and Peripheral Blood Mononuclear Cells (PBMCs). They identified a gene expression signature associated with increased inflammation and immune activation that was present only in liver and PBMC samples from co-infected patients. ${ }^{66}$ The researchers also identified liver- and PBMCspecific signatures enriched with fibrogenic/hepatic stellate activation and proinflammatory genes respectively (Table 1). ${ }^{66}$ Zhao et al. did microarray analysis on $\mathrm{CD} 8^{+} \mathrm{T}$ cells from HIV/HCV-co-infected or mono-infected treatment-naive individuals. ${ }^{62}$ They identified 72 transcript IDs to be differentially expressed ( $>2$ fold and $\mathrm{P}<0.05$ ) in comparisons between HIV/HCV-co-infected and HCV-mono-infected groups; more than $80 \%$ of the genes were downregulated in co-infected as compared to monoinfected patients. ${ }^{62}$ Many of the down-regulated genes correlated with the immune response, few examples being genes regulating IL-2 and genes responding to IFN- $\gamma$ down-regulated in the HIV/HCV co-infected groups (Table 1). ${ }^{62}$ Kuntzen et al. studied intrahepatic messenger RNA levels of cytokines and cellular markers defining distinct subsets of inflammatory cells in liver biopsies from 33 HCV-mono-infected and 40 HIV/HCV-co-infected patients. ${ }^{67}$ Increased levels of IFN- $\gamma$, Regulated upon Activation, Normal Tcell Expressed and Secreted proteins (RANTES) and interferon-inducible proteins were significantly higher in co-infected patients as compared to HCV mono-infected patients (Table 1). ${ }^{67}$ Enhanced expression of the genes was probably related to the effector function of CD8+ T cells as suggested by correlations between these cytokines and CD8. In contrast to the previous studies, Kuntzen et al. showed increased expression of IFN- $\gamma{ }^{67}$ The plausible explanation is that $\mathrm{HCV}$-specific cytokine production is influenced by progressive immunodeficiency, ${ }^{73,74}$ but the CD4+ T cell count was well preserved in the study done by Kuntzen et al. ${ }^{67}$ The results of the gene expression studies done on HIV-HCV coinfection are summarized in Table 1.

\section{MicroRNA expression profiling in Hepatitis C virus/HIV-1 co-infection}

A microRNA (miRNA) is a small RNA molecule (17-22 nucleotides) that functions in the post-transcriptional regulation of gene expression. They are transcribed from the nuclear DNA and function via base-pairing with complementary sequences within mRNA molecules, usually resulting in gene silencing via translational repression or target degradation. miRNA expression analysis will provide valuable insights in physiological and pathological processes regarding co-infection.

There has been a lot of research done regarding the importance of various microRNAs in HIV-1 and HCV infection independently. No report has characterized the alterations in microRNA expression profiles upon HIV-1/HCV co-infection in vitro or in patients. But several miRNAs have been identified with the help of the literature search that can play role in HCV/HIV-1 co-infection.

miRNA-122, a liver specific miRNA has been shown to play a critical role in HCV life cycle according to various studies. ${ }^{75-77}$ Of note, miR122 is undetectable in uninfected, quiescent T cells, ${ }^{78}$ but infection of T cell lines significantly up-regulated the expression of miR-122. ${ }^{79}$ These findings can lead us to wonder if the miRNA-122 expression upon HIV-1 infection of CD4+ T cells, monocytes and macrophages can explain the ability of HCV to infect cells beyond hepatocytes in co-infected patients.

As previously mentioned, miR-29 (miR 29a, b and c) has been shown to be down-regulated in hepatocytes upon HCV infection, and miR-
29 over-expression significantly reduced HCV replication. ${ }^{80}$ miR-29a has also been reported to bind HIV-1 3'UTR by base-pair complementarities and target the viral RNA to P-bodies for degradation. ${ }^{81}$ Another independent report characterized that ectopic expression of miR29a inhibits HIV-1 protein Nef, in addition to reducing viral infectivity. ${ }^{82}$ Thus the role of miR-29 in HCV-HIV co-infection needs to be further explored and efforts should be done to further define if the overexpression of miR29 could have dual inhibitory activity in HIV1/HCV co-infected cells.

miR-199a-3p has been associated with progression to liver fibrosis. ${ }^{83}$ Interestingly, while over-expression of miR-199a was shown to inhibit HCV replication by binding to the viral ${ }^{5}$ UTR,${ }^{84}$ it was also reported that HIV-1 infection resulted in greater than two-fold increase in miR-199a levels. ${ }^{85}$ Based on these data, it would be interesting to explore potential role of miR-199a in HCV/HIV-1 co-infection.

miR-223 and miR-150 were shown to inhibit HIV-1 replication by binding to HIV-1 3'UTR enriched in resting CD4 + T cells as compared to activated $\mathrm{CD} 4+\mathrm{T}$ cells claiming their role as anti-HIV miRNAs. ${ }^{86,87}$ miR-223 was also

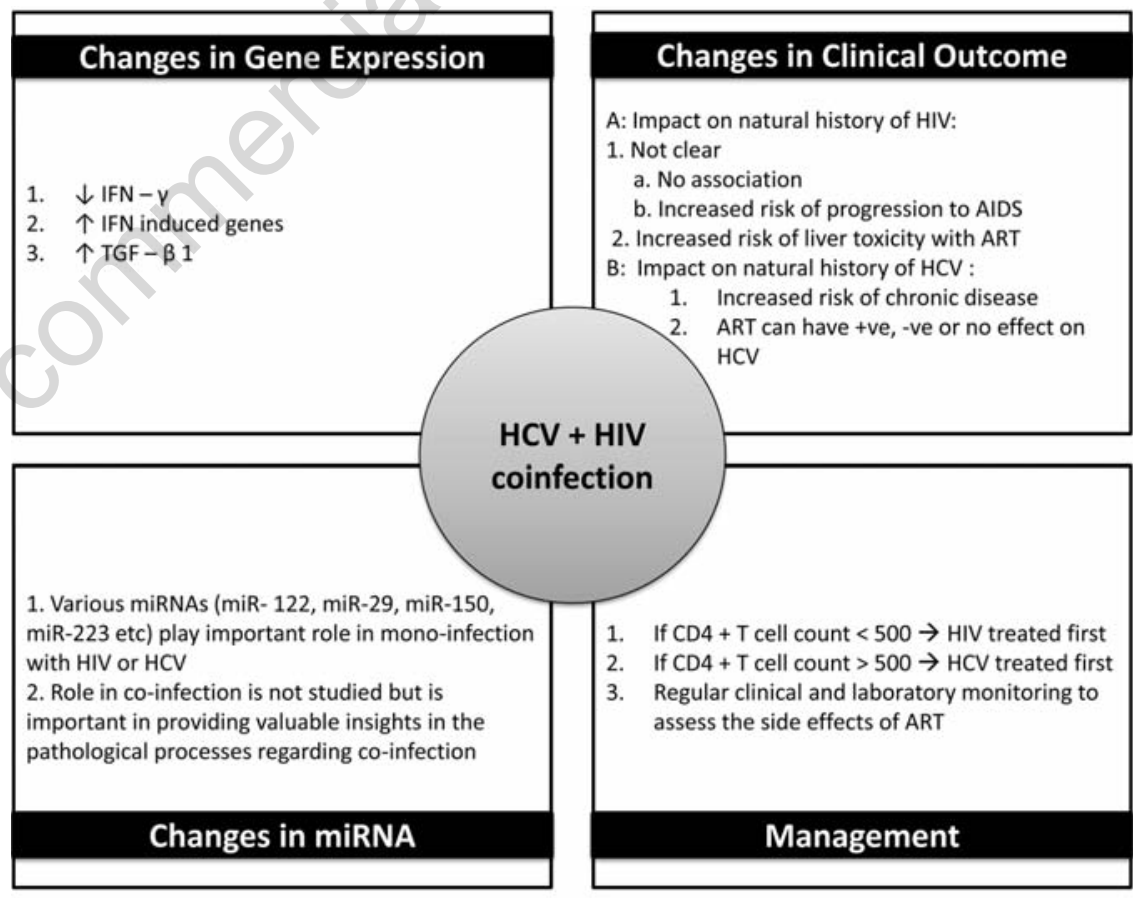

Figure 1. Summary of key findings in HIV-Hepatitis $\mathrm{C}$ virus co-infection discussed in the review. The gene expression studies show decreased level of Interferon (IFN)- $\gamma$, increased level of Tumor Growth Factor (TGF)- $\beta 1$ and increased level of IFIG (interferon induced genes). So far, there have been no miRNA expression studies and there is a need to explore the role of miRNA in the co-infection. The impact of HCV on HIV is not clear and needs to be further explored. HIV has negative impact on HCV with three times greater risk of progression to liver disease in co-infected patients than those infected with $\mathrm{HCV}$ alone. The management of co-infection is directly related to the CD4+T cell count. Regular clinical and laboratory monitoring for the side effects of Antiretroviral therapy (ART) should be done to avoid liver toxicity in co-infected patients. 
down-regulated by about 4.8-fold in HCVinduced hepatocellular carcinoma from HCV infected patients. ${ }^{88}$ However, it has not been investigated whether miR-223 expression is down-regulated in the liver of HCV/HIV-1 coinfected patients with HCC, and if so, whether it would correlate with higher HIV-1 viral load. Up-regulation of miR-150 was seen in chronic hepatitis $\mathrm{C}$ patients ${ }^{80}$ this is interesting, because miR-150 was reported to negatively regulate hepatic stellate cells (HSC). ${ }^{89}$ Overexpression of miR-150 in human hepatic stellate cell lines LX-2 reduced proliferation of the cells (by $\sim 25 \%$ ), increased apoptosis, and reduced $\alpha$-Smooth Muscle Actin ( $\alpha$-SMA) and collagen I levels. ${ }^{89}$

let-7b and let-7g microRNAs were significantly decreased in PBMCs and CD4+ T cells of HIV-1 infected patients as compared to healthy controls or patients, who can naturally control HIV-1 infection e.g. Long-Term Non Progressors (LTNP). ${ }^{90}$ Very recently, let-7b has been shown to bind to HCV protein NS5B and to the 5'UTR, and to significantly suppress HCV infection. ${ }^{91}$ HIV-1 replication can suppress let-7b levels and it is plausible that a decrease in let-7b miRNA in co-infection could potentially augment HCV replication.

The summary of key findings discussed in this review is shown in Figure 1.

\section{Conclusions}

Although studies have been done on the clinical consequences of HIV/HCV co-infection and the influence of HCV on HIV, and vice versa, the mechanisms by which these viruses interact at the cellular level remain unexplored. Genomic and gene regulation studies have opened a new path towards the understanding of early programming of cancer related events during HCV mono and co-infection. A clear understanding of genes involved in this programming in blood and liver are sorely needed, along with a clear understanding of its regulation by miRNA. Together, such studies will be able to point out early therapeutic intervention needed in management of HIV/HCV coinfection.

\section{References}

1. Staples CT Jr, Rimland D, Dudas D. Hepatitis $\mathrm{C}$ in the HIV (human immunodeficiency virus) Atlanta V.A. (Veterans Affairs Medical Center) cohort study (HAVACS): the effect of coinfection on survival. Clin Infect Dis 1999;29:150-4.

2. Yee TT, Griffioen A, Sabin CA, et al. The natural history of $\mathrm{HCV}$ in a cohort of haemophilic patients infected between 1961 and 1985. Gut 2000;47:845-51.

3. Di Martino V, Rufat P, Boyer N, et al. The influence of human immunodeficiency virus coinfection on chronic hepatitis $\mathrm{C}$ in injection drug users: a long-term retrospective cohort study. Hepatology 2001;34: 1193-9.

4. Schreiber GB, Busch MP, Kleinman SH, et al. The risk of transfusion-transmitted viral infections. The Retrovirus Epidemiology Donor Study. N Engl J Med 1996;334:168590.

5. Sherman KE, Rouster SD, Chung RT, et al. Hepatitis C Virus prevalence among patients infected with Human Immunodeficiency Virus: a cross-sectional analysis of the US adult AIDS clinical trials group. Clin Infect Dis 2002;34:831-7.

6. Kingsley LA, Detels R, Kaslow R, et al. Risk factors for seroconversion to human immunodeficiency virus among male homosexuals. Results from the multicenter AIDS cohort study. Lancet 1987;1:345-9.

7. Thomas DL, Zenilman JM, Alter HJ, et al. Sexual transmission of hepatitis $\mathrm{C}$ virus among patients attending sexually transmitted diseases clinics in Baltimore-an analysis of 309 sex partnerships. J Infect Dis 1995;171:768-75.

8. Eyster ME, Alter HJ, Aledort LM, et al. Heterosexual co-transmission of hepatitis $\mathrm{C}$ virus (HCV) and human immunodeficiency virus (HIV). Ann Intern Med 1991;115:764-8.

9. Gray RH, Wawer MJ, Brookmeyer R, et al. Probability of HIV-1 transmission per coital act in monogamous, heterosexual, HIV-1-discordant couples in Rakai, Uganda. Lancet 2001;357:1149-53.

10. Urbanus AT, van de Laar TJ, Stolte IG, et al. Hepatitis C virus infections among HIVinfected men who have sex with men: an expanding epidemic. AIDS 2009;23:F1-7.

11. van de Laar T, Pybus O, Bruisten S, et al. Evidence of a large, international network of HCV transmission in HIV-positive men who have sex with men. Gastroenterology 2009;136:1609-17.

12. Danta M, Brown D, Bhagani S, et al. Recent epidemic of acute hepatitis $\mathrm{C}$ virus in HIV-positive men who have sex with men linked to high-risk sexual behaviours. AIDS 2007;21:983-91.

13. Operskalski EA, Kovacs A. HIV/HCV coinfection: pathogenesis, clinical complications, treatment, and new therapeutic technologies. Curr HIV/AIDS Rep 2011;8:12-22.

14. Kaufmann GR, Perrin L, Pantaleo G, et al. CD4 T-lymphocyte recovery in individuals with advanced HIV-1 infection receiving potent antiretroviral therapy for 4 years: the Swiss HIV Cohort Study. Arch Intern
Med 2003;163:2187-95.

15. Rockstroh JK, Mocroft A, Soriano V, et al. Influence of hepatitis $C$ virus infection on HIV-1 disease progression and response to highly active antiretroviral therapy. J Infect Dis 2005;192:992-1002.

16. Greub G, Ledergerber B, Battegay M, et al. Clinical progression, survival, and immune recovery during antiretroviral therapy in patients with HIV-1 and hepatitis C virus coinfection: the Swiss HIV cohort study. Lancet 2000;356:1800-5.

17. De Luca A, Bugarini R, Lepri AC, et al. Coinfection with hepatitis viruses and outcome of initial antiretroviral regimens in previously naive HIV-infected subjects. Arch Intern Med 2002;162:2125-32.

18. Miller MF, Haley C, Koziel MJ, et al. Impact of hepatitis $\mathrm{C}$ virus on immune restoration in HIV-infected patients who start highly active antiretroviral therapy: a meta-analysis. Clin Infect Dis 2005;41:713-20.

19. Kovacs A, Karim R, Mack WJ, et al. Activation of CD8 T cells predicts progression of HIV infection in women co-infected with hepatitis $\mathrm{C}$ virus. J Infect Dis 2010;201:823-34.

20. Kovacs A, Al-Harthi L, Christensen S, et al. CD8(+) T cell activation in women coinfected with human immunodeficiency virus type 1 and hepatitis $\mathrm{C}$ virus. J Infect Dis 2008;197:1402-7.

21. Gonzalez VD, Falconer K, Blom KG, et al. High levels of chronic immune activation in the T-cell compartments of patients coinfected with hepatitis $\mathrm{C}$ virus and human immunodeficiency virus type 1 and on highly active antiretroviral therapy are reverted by alpha interferon and ribavirin treatment. J Virol 2009;83:11407-11.

22. Potter M, Odueyungbo A, Yang $\mathrm{H}$, et al. Impact of hepatitis $\mathrm{C}$ viral replication on CD4+ T-lymphocyte progression in HIVHCV coinfection before and after antiretroviral therapy. AIDS 2010;24:1857-65.

23. Korner C, Kramer B, Schulte D, et al. Effects of HCV co-infection on apoptosis of CD4+ T-cells in HIV-positive patients. Clin Sci (Lond) 2009;116:861-70.

24. Yacisin K, Maida I, Rios MJ, et al. Hepatitis $\mathrm{C}$ virus coinfection does not affect CD4 restoration in HIV-infected patients after initiation of antiretroviral therapy. AIDS Res Hum Retroviruses 2008;24:935-40.

25. Al-Harthi L, Voris J, Du W, et al. Evaluating the impact of hepatitis $\mathrm{C}$ virus (HCV) on highly active antiretroviral therapy-mediated immune responses in HCV/HIV-coinfected women: role of HCV on expression of primed/memory T cells. J Infect Dis 2006;193:1202-10.

26. Peters L, Mocroft A, Soriano V, et al. Hepatitis $C$ virus coinfection does not influence the CD4 cell recovery in HIV-1- 
infected patients with maximum virologic suppression. J Acquir Immune Defic Syndr. 2009;50:457-63.

27. Sulkowski MS, Moore RD, Mehta SH, et al. Hepatitis C and progression of HIV disease. JAMA 2002;288:199-206.

28. Eyster ME, Diamondstone LS, Lien JM, et al. Natural history of hepatitis $\mathrm{C}$ virus infection in multitransfused hemophiliacs: effect of coinfection with human immunodeficiency virus. The Multicenter Hemophilia Cohort Study. J Acquir Immune Defic Syndr 1993;6:602-10.

29. Villano SA, Vlahov D, Nelson KE, et al. Persistence of viremia and the importance of long-term follow-up after acute hepatitis C infection. Hepatology 1999;29:908-14.

30. Thomas DL, Astemborski J, Rai RM, et al. The natural history of hepatitis $\mathrm{C}$ virus infection: host, viral, and environmental factors. JAMA 2000;284:450-6.

31. Monga HK, Rodriguez-Barradas MC, Breaux K, et al. Hepatitis C virus infection-related morbidity and mortality among patients with human immunodeficiency virus infection. Clin Infect Dis 2001;33:240-7.

32. Darby SC, Ewart DW, Giangrande PL, et al. Mortality from liver cancer and liver disease in haemophilic men and boys in UK given blood products contaminated with hepatitis C. UK Haemophilia Centre Directors' Organisation. Lancet 1997;350: 1425-31.

33. Thomas DL, Shih JW, Alter HJ, et al. Effect of human immunodeficiency virus on hepatitis $\mathrm{C}$ virus infection among injecting drug users. J Infect Dis 1996;174:690-5.

34. Eyster ME, Fried MW, Di Bisceglie AM, et al. Increasing hepatitis $\mathrm{C}$ virus RNA levels in hemophiliacs: relationship to human immunodeficiency virus infection and liver disease. Multicenter Hemophilia Cohort Study. Blood 1994;84:1020-3.

35. Graham CS, Baden LR, Yu E, et al. Influence of human immunodeficiency virus infection on the course of hepatitis $\mathrm{C}$ virus infection: a meta-analysis. Clin Infect Dis 2001;33:562-9.

36. Thein HH, Yi Q, Dore GJ, et al. Natural history of hepatitis $\mathrm{C}$ virus infection in HIVinfected individuals and the impact of HIV in the era of highly active antiretroviral therapy: a meta-analysis. AIDS 2008;22: 1979-91.

37. Qurishi N, Kreuzberg C, Luchters G, et al. Effect of antiretroviral therapy on liverrelated mortality in patients with HIV and hepatitis $\mathrm{C}$ virus coinfection. Lancet 2003;362:1708-13.

38. Brau N, Salvatore M, Rios-Bedoya CF, et al. Slower fibrosis progression in HIV/HCVco-infected patients with successful HIV suppression using antiretroviral therapy. J
Hepatol 2006;44:47-55.

39. Sherman KE, Andersen JW, Butt AA, et al. Sustained long-term antiviral maintenance therapy in HCV/HIV-co-infected patients (SLAM-C). J Acquir Immune Defic Syndr 2010;55:597-605.

40. Sterling RK, Wegelin JA, Smith PG, et al. Similar progression of fibrosis between HIV/HCV-infected and HCV-infected patients: analysis of paired liver biopsy samples. Clin Gastroenterol Hepatol 2010;8:1070-6.

41. Mehta SH, Thomas DL, Torbenson M, et al. The effect of antiretroviral therapy on liver disease among adults with HIV and hepatitis C coinfection. Hepatology 2005;41:12331.

42. Mocroft A, Soriano V, Rockstroh J, et al. Is there evidence for an increase in the death rate from liver-related disease in patients with HIV? AIDS 2005;19:2117-25.

43. Smit C, van den Berg C, Geskus R, et al. Risk of hepatitis-related mortality increased among hepatitis $\mathrm{C}$ virus/HIV-coinfected drug users compared with drug users infected only with hepatitis $\mathrm{C}$ virus: a 20-year prospective study. J Acquir Immune Defic Syndr 2008;47:221-5.

44. Maida I, Nunez M, Rios MJ, et al. Severe liver disease associated with prolonged exposure to antiretroviral drugs. J Acquir Immune Defic Syndr 2006;42:177-82.

45. Sulkowski MS, Mehta SH, Torbenson M, et al. Hepatic steatosis and antiretroviral drug use among adults co-infected with HIV and hepatitis C virus. AIDS 2005;19: 585-92.

46. Zylberberg H, Pialoux G, Carnot F, et al. Rapidly evolving hepatitis $\mathrm{C}$ virus-related cirrhosis in a human immunodeficiency virus-infected patient receiving triple antiretroviral therapy. Clin Infect Dis 1998;27: $1255-8$.

47. Vento S, Garofano T, Renzini C, et al. Enhancement of hepatitis $\mathrm{C}$ virus replication and liver damage in HIV-co-infected patients on antiretroviral combination therapy. AIDS 1998;12:116-7.

48. Sulkowski MS, Mast EE, Seeff LB, et al. Hepatitis $\mathrm{C}$ virus infection as an opportunistic disease in persons infected with human immunodeficiency virus. Clin Infect Dis 2000;30 Suppl 1:S77-84.

49. Ghany MG, Strader DB, Thomas DL, et al. Diagnosis, management, and treatment of hepatitis C: an update. Hepatology 2009;49:1335-74.

50. Ghany MG, Nelson DR, Strader DB, et al. An update on treatment of genotype 1 chronic hepatitis $\mathrm{C}$ virus infection: 2011 practice guideline by the American Association for the study of liver diseases. Hepatology 2011;54:1433-44.

51. Soriano V, Garcia-Samaniego J, Bravo R, et al. Interferon alpha for the treatment of chronic hepatitis $\mathrm{C}$ in patients infected with human immunodeficiency virus. Hepatitis-HIV Spanish study group. Clin Infect Dis 1996;23:585-91.

52. Soriano Va, Puoti Mb, Sulkowski Mc, et al. Care of patients co-infected with HIV and hepatitis C virus: 2007 updated recommendations from the HCV-HIV International Panel AIDS 2007;21:1073-89.

53. Tien PC. Management and treatment of hepatitis $\mathrm{C}$ virus infection in HIV-infected adults: recommendations from the Veterans Affairs Hepatitis $\mathrm{C}$ resource center program and national Hepatitis $\mathrm{C}$ program office. Am J Gastroenterol 2005;100: 2338-54.

54. Avidan NU, Goldstein D, Rozenberg L, et al. Hepatitis $\mathrm{C}$ viral kinetics during treatment with peg IFN-alpha-2b in HIV/HCV co-infected patients as a function of baseline CD4+ T-cell counts. J Acquir Immune Defic Syndr 2009;52:452-8.

55. Vento S, Di Perri G, Cruciani M, et al. Rapid decline of CD4+ cells after IFN alpha treatment in HIV-1 infection. Lancet 1993;341:958-9.

56. Pesce A, Taillan B, Rosenthal E, et al. Opportunistic infections and CD4 lymphocytopenia with interferon treatment in HIV-1 infected patients. Lancet 1993;341:1597.

57. Soriano V, Sulkowski M, Bergin C, et al. Care of patients with chronic hepatitis $\mathrm{C}$ and HIV co-infection: recommendations from the HIV-HCV International Panel. AIDS 2002;16:813-28.

58. McGovern BH, Ditelberg JS, Taylor LE, et al. Hepatic steatosis is associated with fibrosis, nucleoside analogue use, and hepatitis $\mathrm{C}$ virus genotype 3 infection in HIV-seropositive patients. Clin Infect Dis 2006;43:365-72.

59. Abbate I, Cappiello G, Rosati S, et al. Intrahepatic messenger RNA levels for interferons and related genes in hepatitis $\mathrm{C}$ virus/HIV co-infected patients. AIDS 2004;18:691-2.

60. Blackard JT, Komurian-Pradel F, Perret M, et al. Intrahepatic cytokine expression is downregulated during HCV/HIV co-infection. J Med Virol 2006;78:202-7.

61. Walters KA, Smith MW, Pal S, et al. Identification of a specific gene expression pattern associated with HCV-induced pathogenesis in HCV- and HCV/HIV-infected individuals. Virology 2006;350:453-64.

62. Zhao J, Yi L, Lu J, et al. Transcriptomic assay of $\mathrm{CD} 8+\mathrm{T}$ cells in treatment-naive HIV, HCV-mono-infected and HIV/HCV-coinfected Chinese. PLoS One 2012;7: e45200.

63. Flynn JK, Dore GJ, Matthews G, et al. Impaired Hepatitis C Virus (HCV)-specific 
interferon-gamma responses in individuals with HIV who acquire HCV infection: correlation with CD4+ T-cell counts. J Infect Dis 2012;206:1568-76.

64. Gonzalez SA, Zhang C, Fiel MI, et al. Hepatic inflammatory cytokine mRNA expression in hepatitis $\mathrm{C}$ virus-human immunodeficiency virus co-infection. $\mathrm{J}$ Viral Hepat 2008;15:331-8.

65. Kottilil S, Yan MY, Reitano KN, et al. Human immunodeficiency virus and hepatitis $\mathrm{C}$ infections induce distinct immunologic imprints in peripheral mononuclear cells. Hepatology 2009;50:34-45.

66. Rasmussen AL, Wang IM, Shuhart MC, et al. Chronic immune activation is a distinguishing feature of liver and PBMC gene signatures from HCV/HIV co-infected patients and may contribute to hepatic fibrogenesis. Virology 2012;430:43-52.

67. Kuntzen T, Tural C, Li B, et al. Intrahepatic mRNA expression in hepatitis $\mathrm{C}$ virus and HIV/hepatitis C virus co-infection: infiltrating cells, cytokines, and influence of HAART. AIDS 2008;22:203-10.

68. Benhamou Y, Di Martino V, Bochet M, et al. Factors affecting liver fibrosis in human immunodeficiency virus-and hepatitis $\mathrm{C}$ virus-co-infected patients: impact of protease inhibitor therapy. Hepatology 2001; 34:283-7.

69. Mohsen AH, Easterbrook PJ, Taylor C, et al. Impact of human immunodeficiency virus (HIV) infection on the progression of liver fibrosis in hepatitis $\mathrm{C}$ virus infected patients. Gut 2003;52:1035-40.

70. Martinez-Sierra C, Arizcorreta A, Diaz F, et al. Progression of chronic hepatitis $\mathrm{C}$ to liver fibrosis and cirrhosis in patients coinfected with hepatitis $\mathrm{C}$ virus and human immunodeficiency virus. Clin Infect Dis 2003;36:491-8.

71. Mizukoshi E, Kaneko S, Yanagi M, et al. Upregulation of type I interferon receptor by IFN-gamma. J Interferon Cytokine Res 1999;19:1019-23.
72. Garba ML, Pilcher CD, Bingham AL, et al. HIV antigens can induce TGF-beta(1)-producing immunoregulatory CD8+ T cells. J Immunol 2002;168:2247-54.

73. Kim AY, Lauer GM, Ouchi K, et al. The magnitude and breadth of hepatitis $\mathrm{C}$ virus-specific CD8+ $\mathrm{T}$ cells depend on absolute CD4+ T-cell count in individuals co-infected with HIV-1. Blood 2005;105: 1170-8.

74. Dutoit V, Ciuffreda D, Comte D, et al. Differences in HCV-specific T cell responses between chronic HCV infection and HIV/HCV co-infection. Eur J Immunol 2005;35:3493-504.

75. Jopling CL, Yi M, Lancaster AM, et al. Modulation of hepatitis $\mathrm{C}$ virus RNA abundance by a liver-specific MicroRNA. Science 2005;309:1577-81.

76. Roberts AP, Lewis AP, Jopling CL. miR-122 activates hepatitis $\mathrm{C}$ virus translation by $\mathrm{a}$ specialized mechanism requiring particular RNA components. Nucleic Acids Res 2011;39:7716-29.

77. Lewis AP, Jopling CL. Regulation and biological function of the liver-specific miR122. Biochem Soc Trans 2010;38:1553-7.

78. Manfe V, Biskup E, Rosbjerg A, et al. miR122 regulates p53/Akt signalling and the chemotherapy-induced apoptosis in cutaneous T-cell lymphoma. PLoS One 2012;7: e29541.

79. Triboulet R, Mari B, Lin YL, et al. Suppression of microRNA-silencing pathway by HIV-1 during virus replication. Science 2007;315:1579-82.

80. Bandyopadhyay S, Friedman RC, Marquez RT, et al. Hepatitis C virus infection and hepatic stellate cell activation downregulate miR-29: miR-29 overexpression reduces hepatitis $\mathrm{C}$ viral abundance in culture. J Infect Dis 2011;203:1753-62.

81. Nathans R, Chu CY, Serquina AK, et al. Cellular microRNA and $\mathrm{P}$ bodies modulate host-HIV-1 interactions. Mol Cell 2009;34: 696-709.
82. Ahluwalia JK, Khan SZ, Soni K, et al. Human cellular microRNA hsa-miR-29a interferes with viral nef protein expression and HIV-1 replication. Retrovirology 2008;5:117.

83. Murakami Y, Toyoda H, Tanaka M, et al. The progression of liver fibrosis is related with overexpression of the miR-199 and 200 families. PLoS One 2011;6:e16081.

84. Murakami Y, Aly HH, Tajima A, et al. Regulation of the hepatitis $\mathrm{C}$ virus genome replication by miR-199a. J Hepatol 2009; 50:453-60.

85. Hayes AM, Qian S, Yu L, et al. Tat RNA silencing suppressor activity contributes to perturbation of lymphocyte miRNA by HIV-1. Retrovirology 2011;8:36.

86. Huang J, Wang F, Argyris E, et al. Cellular microRNAs contribute to HIV-1 latency in resting primary CD4+ T lymphocytes. Nat Med 2007;13:1241-7.

87. Wang X, Ye L, Hou W, et al. Cellular microRNA expression correlates with susceptibility of monocytes/macrophages to HIV-1 infection. Blood 2009;113:671-4.

88. Wong QW, Lung RW, Law PT, et al. MicroRNA-223 is commonly repressed in hepatocellular carcinoma and potentiates expression of Stathmin1. Gastroenterology 2008;135:257-69.

89. Venugopal SK, Jiang J, Kim TH, et al. Liver fibrosis causes downregulation of miRNA150 and miRNA-194 in hepatic stellate cells, and their overexpression causes decreased stellate cell activation. Am J Physiol Gastrointest Liver Physiol 2010; 298:G101-6.

90. Swaminathan S, Suzuki K, Seddiki N, et al. Differential regulation of the Let-7 family of microRNAs in CD4+ T cells alters IL-10 expression. J Immunol 2012;188:6238-46.

91. Cheng JC, Yeh YJ, Tseng CP, et al. Let-7b is a novel regulator of hepatitis $\mathrm{C}$ virus replication. Cell Mol Life Sci 2012;69:2621-33. 